\title{
Opioid Prescribing During Delivery Hospitalization Associated with Increased Postpartum Emergency Department Utilization
}

\author{
Grace Bagwell ADAMS, PhD, \\ Courtney R. YARBROUGH, PhD \\ Ms. Samantha J. HARRIS, MPA \\ Amanda J. ABRAHAM, PhD
}

This study was conducted in Athens, Georgia at the University of Georgia's College of Public Health: Department of Health Policy \& Management, at the University of Georgia's School of Public and International Affairs: Department of Public Administration \& Policy, and in Atlanta, Georgia at Emory University's Rollins School of Public Health: Department of Health Policy and Management.

The authors report no conflict of interest.

This work has been presented at the American Society of Health Economists (ASHEcon) Conference in Washington, DC on June 26th, 2019 and at the International Health Economics Association (iHEA) World Congress in Basel, Switzerland on July 15th, 2019.

Corresponding author:

Grace Bagwell ADAMS, $\mathrm{PhD}$

University of Georgia

College of Public Health

Department of Health Policy \& Management

211D Wright Hall, Health Sciences Campus

100 Foster Road

Athens, GA 30602

gbagwell@uga.edu 


\section{Structured Abstract}

Background: Empirical evidence shows postpartum women are prescribed opioids at high rates following both cesarean and vaginal delivery. Beyond this, little is known about opioid prescribing to postpartum mothers following delivery hospitalization and the resulting impacts for maternal health. Postpartum women may be particularly vulnerable to adverse health effects from inappropriate prescribing.

Objectives: This study examines the effects of postpartum opioid prescribing on emergency department (ED) utilization, controlling for delivery type and other maternal characteristics.

Study Design: We conduct a retrospective cohort study using 2008-2016 data from the Medical Expenditure Panel Survey (MEPS).

Results: We find $31 \%$ of women received a new opioid prescription following delivery, and that receipt of an opioid prescription following delivery hospitalization is associated with a $67 \%$ increase in the odds of an ED visit.

Conclusion: This study is one of the first to test the relationship between opioid prescribing and healthcare utilization among this population, contributing critical information to our understanding of implications for opioid prescribing after childbirth for postpartum women. 
medRxiv preprint doi: https://doi.org/10.1101/2020.10.26.20219923; this version posted October 27, 2020. The copyright holder for this preprint (which was not certified by peer review) is the author/funder, who has granted medRxiv a license to display the preprint in perpetuity.

All rights reserved. No reuse allowed without permission.

\section{Introduction}

The opioid epidemic and maternal mortality are concurrent public health crises in the United States that result in premature death and decreases in life expectancy.(1-3) The intersection of these two crises is an area that merits the attention of policymakers, clinicians, and researchers. Adults of reproductive age are among those most affected by inappropriate opioid prescribing, opioid misuse, and opioid use disorder (OUD). Indeed, much attention has been garnered by documentation of the $400 \%$ increase in OUD among pregnant women between 1999 and 2014.(4-7) One target subpopulation that has been studied over the last few years with new focus is postpartum women who are opioid-naive that receive opioid prescriptions following delivery. Our study examines one of the lesser known pathways between these women receiving opioid scripts and their subsequent hospital utilization patterns.

In 2018, the American College of Obstetrics and Gynecology (ACOG) released the first ever guidelines for postoperative cesarean care, calling for a reduction in postoperative opioid prescribing. While ACOG recognizes the prevalence of opioid prescriptions for cesarean deliveries as a public health issue, it is important that we examine opioid prescribing for all births. Recent evidence shows that both cesarean and vaginal deliveries frequently result in receipt of an opioid prescription at delivery hospitalization.

Postpartum women who are opioid-naive may be particularly vulnerable to adverse health effects from opioids as they suffer from elevated rates of acute and chronic pain and are at risk of experiencing postpartum depression and anxiety. The potential link between opioid prescribing among opioid-naive women and their health care utilization and health outcomes is not well understood. 
medRxiv preprint doi: https://doi.org/10.1101/2020.10.26.20219923; this version posted October 27, 2020. The copyright holder for this preprint (which was not certified by peer review) is the author/funder, who has granted medRxiv a license to display the preprint in perpetuity.

All rights reserved. No reuse allowed without permission.

This paper examines the relationship between opioid prescribing and emergency department (ED) utilization after delivery hospitalization among postpartum, opioid-naive women. Using data from the Medical Expenditure Panel Survey (MEPS) from 2008 through 2016, we employ a logistic regression approach to estimate the association between receiving an opioid prescription following delivery hospitalization and ED use. Controlling for delivery type, insurance status, and a host of other demographic and socioeconomic characteristics, we find that receiving an opioid prescription is associated with a significant increase in the odds of ED use for postpartum women following delivery.

The literature on prescribing patterns for postpartum women has highlighted the prevalence of receiving an opioid prescription after birth and has shown important and significant differences in prescribing patterns based on delivery type-- vaginal or cesarean delivery.(8) Regardless of delivery type, however, rates of opioid analgesic prescribing to postpartum women are high and have clinical and practical implications for both patients and their infant children. Research is needed to better understand the implications of opioid prescribing patterns in this population.

Understanding how prescription opioids are related to healthcare utilization and health outcomes can contribute new knowledge to efforts aimed at mitigating the opioid crisis and efforts to improve maternal health outcomes. Clinicians and policy makers, with greater understanding of the link between prescribing behavior related to both healthcare utilization and outcomes for postpartum women, will have increased ability to make more informed clinical decisions. 
medRxiv preprint doi: https://doi.org/10.1101/2020.10.26.20219923; this version posted October 27, 2020. The copyright holder for this preprint (which was not certified by peer review) is the author/funder, who has granted medRxiv a license to display the preprint in perpetuity.

All rights reserved. No reuse allowed without permission.

\section{Materials \& Methods}

To study the relationship between opioid prescribing and emergency department visits for postpartum mothers, we rely on publicly available data from the MEPS from 2008 through 2016. The MEPS is a nationally representative survey of non-institutionalized individuals' health care utilization and spending conducted by the federal Agency for Healthcare Research and Quality. It follows survey participants during five data collection rounds over two-year, overlapping panels of approximately 16,000 individuals per panel.

We collect all childbirths from the Hospital Inpatient Stays files. Over the nine years of our study period, there were 3,569 live births. For those delivering mothers, we obtain socioeconomic, demographic, and insurance coverage variables from the Full-Year Consolidated Data files. We obtain data on mothers' outpatient prescription fills from the Prescribed Medicines files and identify opioid prescriptions according to Multum drug category ${ }^{1}$. We create a dichotomous variable for a mother filling any opioid prescription in the birth round. To avoid confounding from opioid prescriptions resulting from an ED visit (unrelated to delivery), we omit opioid prescriptions linked in the data to non-delivery-related ED visits.

We limit our sample to mothers considered to be "opioid-naive" prior to delivery by excluding those who filled a prescription for any opioid in the survey round prior to delivery, in addition to births from mothers who received any medication treatment for opioid use disorder ${ }^{2}$ during the survey.(9) As such, we exclude births that occur during the first survey round in order to observe a full round of prenatal prescribing. We also exclude births that occur in the final (fifth) survey round in order to allow a sufficient length of time for post-delivery observation of

\footnotetext{
${ }^{1}$ Narcotic Analgesics or Narcotic Analgesic Combinations

2 Methadone, buprenorphine, or naltrexone
} 
medRxiv preprint doi: https://doi.org/10.1101/2020.10.26.20219923; this version posted October 27, 2020. The copyright holder for this preprint (which was not certified by peer review) is the author/funder, who has granted medRxiv a license to display the preprint in perpetuity.

All rights reserved. No reuse allowed without permission.

our outcome variable. Finally, we exclude mothers who experienced a multiple birth (i.e., twins or triplets). Our final sample includes 2,245 births occurring in survey rounds two through four that met the other criteria described above.

For our outcome variables, we obtain records of ED visits for mothers from the Emergency Rooms Visits files, which contain Clinical Classification Codes (CCC) describing the reason for the ED visit. For each individual, we construct a dichotomous dependent variable indicating whether the mother had any ED visits during or after the month of birth. We exclude ED visits coded in MEPS as being prenatal- or delivery-related and those with CCCs related to pregnancy or delivery. ${ }^{3}$

We estimate descriptive statistics on the sample, disaggregated by those who received an opioid prescription and those who did not. Then, t-tests are estimated to examine the differences in means for variables of interest including receiving an opioid prescription, receipt by delivery type, and ED visits for those with and without an opioid prescription.

We then use a series of logistic regression models to measure the association between a postpartum mother filling an opioid prescription and the odds of a subsequent ED visit. Conditional on having an ED visit, we then estimate a model to predict the count of ED visits among postpartum women as associated with receipt of an opioid prescription. We control for a number of characteristics including whether the delivery was by cesarean section, mother's age, race/ethnicity, educational attainment, health insurance status, poverty status, marital status, and family size.

We include fixed effects for year and geographic census region to control for secular time trends and for time-invariant regional characteristics. Because giving birth in an earlier survey

${ }^{3}$ Clinical Classification Codes 176-196 
medRxiv preprint doi: https://doi.org/10.1101/2020.10.26.20219923; this version posted October 27, 2020. The copyright holder for this preprint (which was not certified by peer review) is the author/funder, who has granted medRxiv a license to display the preprint in perpetuity.

All rights reserved. No reuse allowed without permission.

round provides more opportunity for an ED visit to occur in the remainder of the survey period, we control for the number of months from delivery to the end of the survey. All analyses were conducted in Stata 15 using the MEPS-provided sample weights to make the results nationally representative. The study was based on de-identified data from a U.S. government public use dataset and was therefore exempt from IRB approval.

\section{Limitations}

This study has several limitations of note. First, the small sample size constrains the predictive power in model estimation. Second, visiting the ED after delivery is a relatively rare event, thus the sample size is additionally constricted by the rarity of observing an ED visit. Third, we do not observe the timing of the ED visit--the observations are not at the patient-day level. Rather, we observe women in the birth month and in subsequent survey rounds after the birth month. We did, however, conduct sensitivity analyses to limit ED visits to the month after birth and then through the end of the survey participation period. Results are consistent across specification. Fourth, a we do not observe delivery-related injuries; we do, however, control for delivery type.

\section{Results}

Exhibit 1 displays summary statistics of the final sample, which includes data on mothers from 2,245 births - 69\% vaginal deliveries and 31\% cesarean. Mothers were prescribed a postpartum opioid in $30.0 \%$ of cases. Approximately $12 \%$ of new mothers visited the ED during the survey after their delivery; however, among women who received an opioid prescription, $16 \%$ 
medRxiv preprint doi: https://doi.org/10.1101/2020.10.26.20219923; this version posted October 27, 2020. The copyright holder for this preprint (which was not certified by peer review) is the author/funder, who has granted medRxiv a license to display the preprint in perpetuity.

All rights reserved. No reuse allowed without permission.

had a subsequent visit to the ED compared with $10 \%$ of women who did not receive an opioid $(\mathrm{p}<0.01)$.

Approximately $40 \%$ of women who received an opioid at birth were white compared to $31 \%$ of women who did not receive an opioid at birth $(\mathrm{p}<.01)$. Conversely, $30 \%$ of women who received an opioid at birth were Hispanic compared to $40 \%$ of births with no opioid prescription $(\mathrm{p}<.01)$. Mother's age, some college or an Associate's degree, and being insured were all significantly higher in births with an opioid prescription. Having less than a high school education, falling below the Federal Poverty Level, and smaller household size were significantly lower in births with an opioid prescription.

Exhibit 2 shows a comparison of means by delivery type, opioid prescription filled, and ED visit. The first graph shows statistically significant differences in the percentage of women with vaginal versus cesarean deliveries $(\mathrm{p}<.01)$. The second shows the percentage of women in the total sample who fill an opioid prescription and then disaggregates the sample by delivery type. The percentage of women who received an opioid prescription at birth was significantly higher for women delivering via cesarean $(\mathrm{p}<.01)$. Finally, the third graph shows the percentage of women who experience an ED visit for the total sample and by delivery type. While there is a difference in the percentage of women with an ED visit by delivery type, it is not statistically significant $(\mathrm{p}<.30)$.

Exhibit 3 presents the difference in the percentage of postpartum women experiencing an ED visit by those who received an opioid prescription versus those that did not. Women who received an opioid prescription were significantly more likely to have an ED visit than those who $\operatorname{did} \operatorname{not}(\mathrm{p}<.01)$ 
medRxiv preprint doi: https://doi.org/10.1101/2020.10.26.20219923; this version posted October 27, 2020. The copyright holder for this preprint (which was not certified by peer review) is the author/funder, who has granted medRxiv a license to display the preprint in perpetuity.

All rights reserved. No reuse allowed without permission.

Logistic regression results showing the relationship estimated between opioid receipt and probability of having an ED visit are shown in Exhibit 4. Among women who filled an opioid prescription after delivery hospitalization, there is a 1.69 increase in the odds of having an ED visit $(\mathrm{p}<.05)$.

Delivery type was not significantly associated with odds of an ED visit for postpartum women. Maternal age was negatively associated with odds of an ED visit $(\mathrm{p}<.05)$. The odds of an ED visit were higher for women with some college or an Associate's degree (1.86, $\mathrm{p}<.05)$, relative to women with no high school degree or a GED. Finally, the odds of an ED visit were lower for women living in the West, South, and Midwest relative to those in the Northeast $(\mathrm{p}<.05)$.

A second model was estimated to test whether there was an association between receipt of an opioid and the number of times a postpartum woman visited the ED. Conditional on having an ED visit, we found no association between the receipt of an opioid prescription and the number of times a postpartum woman visited the ED. Finally, as a sensitivity analysis, we examined the quantity of opioids prescribed (as measured in morphine milligram equivalents, or MMEs) and also found that the MMEs were not a significant predictor of having an ED visit.

\section{Discussion}

We find that filling an opioid prescription after delivery hospitalization is associated with a 1.67 , or $67 \%$, increase in the odds of postpartum, opioid-naive women visiting the ED after hospital discharge. Additional analyses showed no statistically significant effect for MMEs on ED utilization; likewise, conditional on an ED visit, receipt of an opioid prescription does not increase the number of ED visits for postpartum women. Notably, we do not find a significant association between delivery type and ED utilization. 
medRxiv preprint doi: https://doi.org/10.1101/2020.10.26.20219923; this version posted October 27, 2020. The copyright holder for this preprint (which was not certified by peer review) is the author/funder, who has granted medRxiv a license to display the preprint in perpetuity.

All rights reserved. No reuse allowed without permission.

This study builds on recent descriptive work that finds significant variation in opioid prescribing patterns among postpartum women by delivery type.(8, 10,11) These studies highlight the prevalence of receiving a postpartum prescription; specifically, Badreldin et al. found that almost a third (30.4\%) of women who delivered vaginally and $87 \%$ of women who delivered via cesarean received an opioid analgesic, respectively.(10) Contributing to the reliance on prescribing of opioids following delivery is the high cesarean rate in the United States. In 2015, there were 1.3 million cesarean deliveries $-32 \%$ of all births - making cesareans the most common inpatient surgical procedure in the U.S. [25]

In April of 2019, a study published in the American Journal of Obstetrics and Gynecology found that prescription of opioid analgesics after delivery was associated with persistent opioid use, with marginal differences by delivery type.(12) This study showed new evidence that while opioids are prescribed at higher rates for cesarean section deliveries, it could be the initial opioid prescription that is a greater predictor of persistent opioid use rather than the cesarean section itself.(12-14) Osmundson and colleagues estimated that postpartum opioid prescribing was linked to 21,576 new persistent opioid users annually.(12)

Outside of the research on the opioid crisis, the clinical standard of care for new mothers includes little interaction with healthcare clinicians after giving birth. Most women receive a sixweek postpartum check and then are released from the care of their obstetrician until it is time for their annual wellness exam a year later. Clinical standards of care and the lack of interaction with providers after birth stand in stark juxtaposition to the standard for newborns and infants through the first year. Infants have many points of contact with pediatricians in the first year through a standardized well visit schedule. 
medRxiv preprint doi: https://doi.org/10.1101/2020.10.26.20219923; this version posted October 27, 2020. The copyright holder for this preprint (which was not certified by peer review) is the author/funder, who has granted medRxiv a license to display the preprint in perpetuity.

All rights reserved. No reuse allowed without permission.

Sparse follow-up care for postpartum women potentially increases the risk for adverse physical and mental health outcomes. Opioid prescriptions could exacerbate this vulnerability, as women receiving an opioid prescription could be more likely to experience postpartum anxiety and depression. Empirical evidence has shown that opioid use is associated with depression; in addition to work that shows associations between OUD, depression, and anxiety as comorbidities. Given that women are at risk for postpartum depression and postpartum anxiety after birth, additional research is needed to examine whether opioid prescribing is associated with increased incidence of postpartum depression, postpartum anxiety, and OUD.

There are a number of avenues through which opioid prescriptions could influence the propensity for a postpartum woman to visit the ED. These include but are not limited to increases in postpartum depression or anxiety, sedation leading to accidents and injuries, lack of mental clarity leading to suboptimal decision making, or other adverse reactions to the opioid medication itself. Clinicians and policy makers weighing these potential risks against the known benefits of opioids should consider work such as a 2017 study by Bateman and colleagues that finds extensive opioid prescribing to women following a cesarean delivery reported no pain improvements related to opioid prescribing. Another study finds that a small number of women receiving post-delivery opioid prescriptions transitioned to long-term, potentially problematic opioid use, with the likelihood of long-term use increasing with substance use disorder risk factors [28].

Significant attention on the opioid crisis and maternal and child health has focused on pregnant women or their infants once born (e.g. Neonatal Abstinence Syndrome, or NAS), not on opioid-naive women at delivery and in the postpartum period. Our study initiates a new line of work to link opioid prescribing after birth to healthcare utilization among postpartum, opioidnaive women. As previously stated, recent work that has focused on postpartum women has fo- 
medRxiv preprint doi: https://doi.org/10.1101/2020.10.26.20219923; this version posted October 27, 2020. The copyright holder for this preprint (which was not certified by peer review) is the author/funder, who has granted medRxiv a license to display the preprint in perpetuity.

All rights reserved. No reuse allowed without permission.

cused on descriptions of prescribing patterns by delivery type and potential associations between opioid prescribing and opioid misuse, abuse, and persistent opioid use.

Our study is important because it addresses a more common scenario than the transition to persistent opioid use or abuse; that is, it examines the experiences of new mothers who receive an opioid pain reliever prescription during the short but vulnerable period immediately after birth. Much of the focus of existing literature is on the effect of opioid use during pregnancy on labor, delivery, and birth outcomes. While understanding the impact of prenatal opioid use is essential, it is also important to examine the potential effects of post-delivery opioid use on maternal health. Clinical and population health researchers have only begun to research new mothers and interactions between opioid prescribing and postpartum health. We call attention to the need for more work on the effect of prescribing on healthcare utilization and health outcomes in addition to OUD. These include but are not limited to behavioral health issues such as postpartum depression and anxiety.

\section{Conclusion}

National crises in both opioids and maternal and child health merit focus in research, policy, and practice. Over the last decade, the opioid crisis and maternal and infant health outcomes (e.g. mortality and other adverse birth outcomes) have grown in magnitude, receiving significant media and research attention. The research examining the link between these two national problems needs more attention and empirical research. In particular, we need a deeper understanding of the causal links between opioid prescribing and maternal and infant health.

Over the last several years, meaningful strides have been made in research on the relationship between opioid prescribing and myriad outcomes of interest. Postpartum-specific work has contributed important descriptive analyses of opioid prescribing, with particular focus on the 
rate of prescription opioids received by delivery type. The current study extends this line of work by looking at the association between postpartum opioid prescribing and ED utilization for women who have given birth, finding significant increases in the odds of ED use for these women despite the type of delivery they experienced.

More research is needed on the direct link between opioids and healthcare utilization and health outcomes for postpartum women and their infants. Concurrent foci of postpartum research must look at postpartum women with OUD as well as opioid-naive women who are prescribed opioids post-delivery. The policy implications of these findings include the importance of adhering to recent clinical guidelines and recommendations from the American College of Obstetricians and Gynecologists for opioid prescribing for postpartum women. The findings of this research may help inform health care practitioners about the implications of opioid prescribing after childbirth and may support the development of alternative pain management strategies for new mothers. 


\section{References}

1. Peahl AF, Smith R, Johnson T, Morgan D, Pearlman M. Better late than never: why obstetricians must implement enhanced recovery after cesarean. American J Obstet Gynecol. 2019.

2. Shiels MS, Chernyavskiy P, Anderson WF, Best AF, Haozous EA, Hartge P, et al. Trends in premature mortality in the USA by sex, race, and ethnicity from 1999 to 2014: an analysis of death certificate data. Lancet. 2017;389(10073):1043-54.

3. Murphy SL, Xu J, Kochanek KD, Arias E. Mortality in the United States, 2017. Hyattsville, MD: National Center for Health Statistics. 2018. Report No.: 328.

4. National Academies of Sciences Engineering and Medicine, Health and Medicine Division, Board on Health Sciences Policy, Committee on Pain Management and Regulatory Strategies to Address Prescription Opioid Abuse. Trends in opioid use, harms, and treatment. In: Phillips JK, Ford MA, Bonnie RJ, editors. Pain management and the opioid epidemic: balancing societal and individual benefits and risks of prescription opioid use. Washington (DC): National Academies Press (US); 2017.

5. Scholl L, Seth P, Kariisa M, Wilson N, Baldwin G. Drug and opioid-involved overdose deaths United States, 2013-2017. MMWR Morb Mortal Wkly Rep. 2019;67(5152):1419-27.

6. Manchikanti L, Fellows B, Janata JW, Pampati V, Grider JS, Boswell M. Opioid epidemic in the United States. Pain Physician. 2012;15(3 Suppl):ES9-38.

7. The number of women with opioid use disorder at labor and delivery quadrupled from 1999-2014. First state-based analysis shows increases in all states studied. CDC Newsroom: Centers for Disease Control and Prevention; 2018.

8. Badreldin N, Grobman WA, Yee LM. Inpatient opioid use after vaginal delivery. American J Obstet Gynecol. 2018;219(6):608. e1-. e7.

9. Shah A, Hayes CJ, Martin BC. Characteristics of initial prescription episodes and likelihood of long-term opioid use-United States, 2006-2015. MMWR Morb Mortal Wkly Rep. 2017;66(10):265.

10. Badreldin N, Grobman WA, Chang KT, Yee LM. Opioid prescribing patterns among postpartum women. American J Obstet Gynecol. 2018;219(1):103. e1-. e8.

11. Osmundson SS, Min JY, Grijalva CG. Opioid prescribing after childbirth: overprescribing and chronic use. Curr Opin Obstet and Gynecol. 2019;31(2):83-9.

12. Osmundson SS, Wiese AD, Min JY, Hawley RE, Patrick SW, Griffin MR, et al. Delivery type, opioid prescribing, and the risk of persistent opioid use after delivery. American J Obstet Gynecol. 2019;220(4):405-7.

13. Sun EC, Darnall BD, Baker LC, Mackey S. Incidence of and risk factors for chronic opioid use among opioid-naive patients in the postoperative period. JAMA Intern Med. 2016;176(9):1286-93.

14. Bateman BT, Franklin JM, Bykov K, Avorn J, Shrank WH, Brennan TA, et al. Persistent opioid use following cesarean delivery: patterns and predictors among opioid-naive women. American J Obstet Gynecol. 2016;215(3):353. e1-. e18. 
Figure 1.

\section{Postpartum ED Visits}

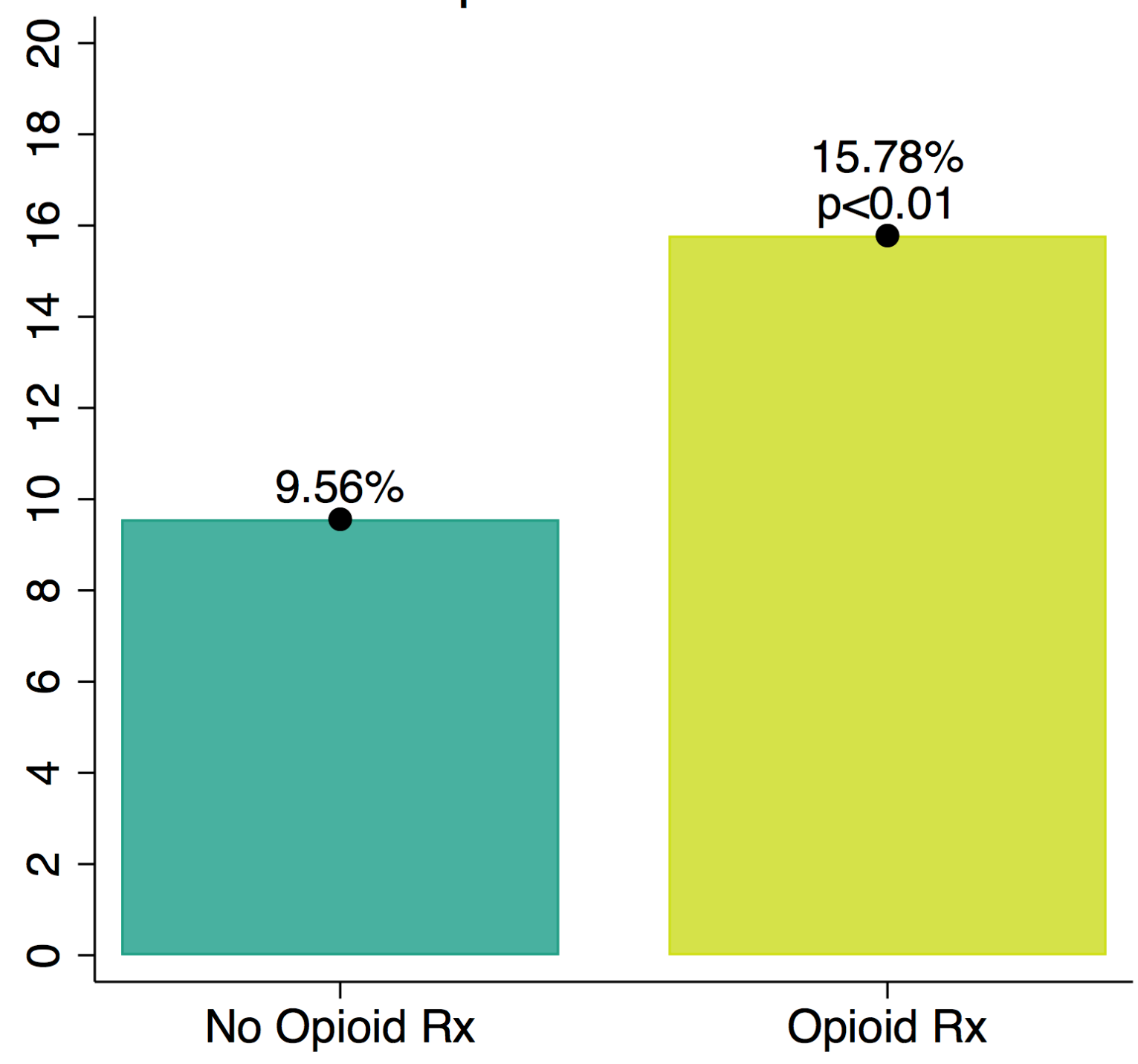


medRxiv preprint doi: https://doi.org/10.1101/2020.10.26.20219923; this version posted October 27, 2020. The copyright holder for this preprint (which was not certified by peer review) is the author/funder, who has granted medRxiv a license to display the preprint in perpetuity.

All rights reserved. No reuse allowed without permission.

Figure 2.
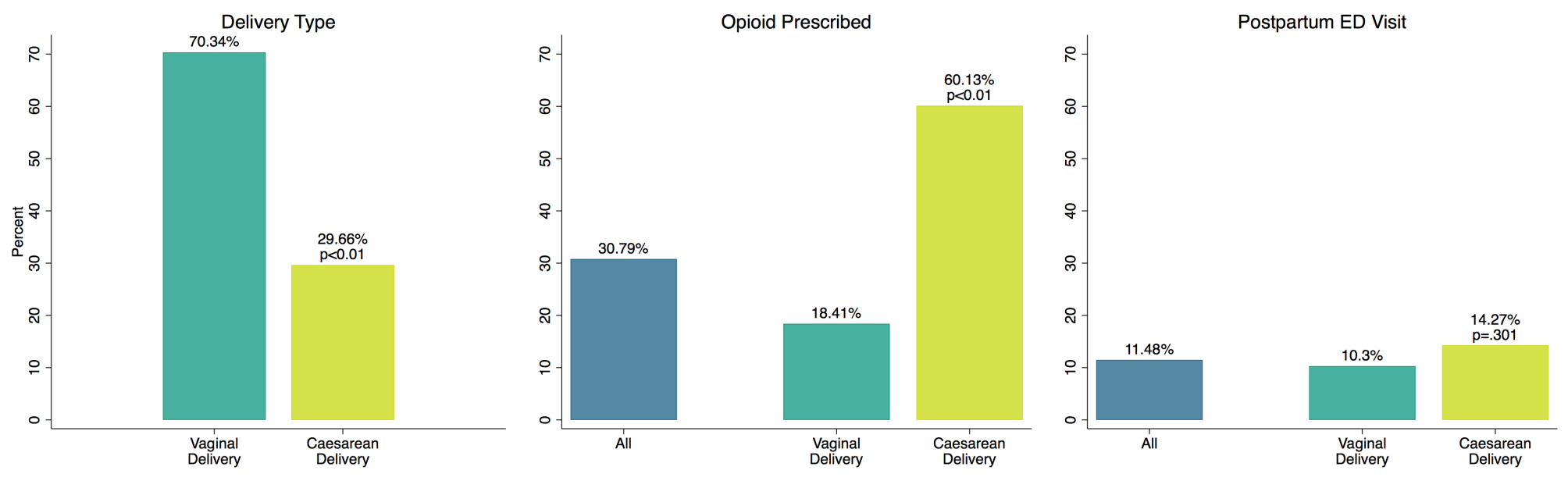

$\mathrm{N}=2245$ 
medRxiv preprint doi: https://doi.org/10.1101/2020.10.26.20219923; this version posted October 27, 2020. The copyright holder for this preprint

(which was not certified by peer review) is the author/funder, who has granted medRxiv a license to display the preprint in perpetuity.

All rights reserved. No reuse allowed without permission.

Table 1. Descriptive Statistics. 
medRxiv preprint doi: https://doi.org/10.1101/2020.10.26.20219923; this version posted October 27, 2020. The copyright holder for this preprint (which was not certified by peer review) is the author/funder, who has granted medRxiv a license to display the preprint in perpetuity.

All rights reserved. No reuse allowed without permission.

\begin{tabular}{|c|c|c|c|}
\hline & $\begin{array}{l}\text { All Births } \\
\text { mean (sd) }\end{array}$ & $\begin{array}{l}\text { Births w/ } \\
\text { Opioid Rx } \\
\text { mean (sd) }\end{array}$ & $\begin{array}{l}\text { Births w/ } \\
\text { Opioid Rs } \\
\text { mean (sd) }\end{array}$ \\
\hline \multicolumn{4}{|l|}{ Dependent Variable: } \\
\hline Any ED Visit & $\begin{array}{c}0.12 \\
(0.33)\end{array}$ & $0.16 \quad(0.37)$ & $\begin{array}{l}0.10 \\
(0.31)\end{array}$ \\
\hline \multicolumn{4}{|l|}{ Independent Variables: } \\
\hline Any Opioid Rx & $\begin{array}{l}0.30 \\
(0.46)\end{array}$ & $1.00 \quad(0.00)$ & $\begin{array}{l}0.00 \\
(0.00)\end{array}$ \\
\hline Caesarean Delivery & $\begin{array}{c}0.31 \\
(0.46)\end{array}$ & $0.58 \quad(0.49)$ & $\begin{array}{l}0.20 \\
(0.40)\end{array}$ \\
\hline White & $\begin{array}{l}0.33 \\
(0.47)\end{array}$ & $0.40 \quad(0.49)$ & $\begin{array}{c}0.31 \\
(0.46)\end{array}$ \\
\hline Black & $\begin{array}{l}0.20 \\
(0.40)\end{array}$ & $0.21 \quad(0.41)$ & $\begin{array}{l}0.20 \\
(0.40)\end{array}$ \\
\hline Hispanic & $\begin{array}{c}0.37 \\
(0.48)\end{array}$ & $0.30 \quad(0.46)$ & $\begin{array}{c}0.40 \\
(0.49)\end{array}$ \\
\hline Asian & $\begin{array}{l}0.07 \\
(0.26)\end{array}$ & $0.07 \quad(0.25)$ & $\begin{array}{l}0.07 \\
(0.26)\end{array}$ \\
\hline Other Race & $\begin{array}{l}0.02 \\
(0.15)\end{array}$ & $0.03 \quad(0.17)$ & $\begin{array}{l}0.02 \\
(0.14)\end{array}$ \\
\hline Mother's Age & $\begin{array}{l}27.77 \\
(6.06)\end{array}$ & $\begin{array}{l}28.15 \\
(5.87)\end{array}$ & $\begin{array}{l}27.60 \\
(6.13)\end{array}$ \\
\hline No HS Deg. & $\begin{array}{c}0.22 \\
(0.42)\end{array}$ & $0.17 \quad(0.38)$ & $\begin{array}{l}0.24 \\
(0.43)\end{array}$ \\
\hline HS Deg./GED & $\begin{array}{l}0.30 \\
(0.46)\end{array}$ & $0.33 \quad(0.47)$ & $\begin{array}{l}0.29 \\
(0.46)\end{array}$ \\
\hline $\begin{array}{l}\text { Some College/Associate's } \\
\text { Deg. }\end{array}$ & $\begin{array}{l}0.24 \\
(0.43)\end{array}$ & $0.26(0.44)$ & $\begin{array}{l}0.23 \\
(0.42)\end{array}$ \\
\hline $\begin{array}{l}\text { Bachelor's Deg. or High- } \\
\text { er }\end{array}$ & $\begin{array}{l}0.23 \\
(0.42)\end{array}$ & $0.24 \quad(0.43)$ & $\begin{array}{l}0.23 \\
(0.42)\end{array}$ \\
\hline Insured & $\begin{array}{l}0.82 \\
(0.39)\end{array}$ & $0.85 \quad(0.36)$ & $\begin{array}{l}0.80 \\
(0.40)\end{array}$ \\
\hline Income $<100 \% \mathrm{FPL}$ & $\begin{array}{l}0.40 \\
(0.49)\end{array}$ & $0.39 \quad(0.49)$ & $\begin{array}{l}0.40 \\
(0.49)\end{array}$ \\
\hline Family Size & $\begin{array}{c}4.38 \\
(1.78)\end{array}$ & $4.19(1.66)$ & $\begin{array}{c}4.47 \\
(1.82)\end{array}$ \\
\hline Married & $\begin{array}{l}0.54 \\
(0.50)\end{array}$ & $0.55 \quad(0.50)$ & $\begin{array}{l}0.54 \\
(0.50)\end{array}$ \\
\hline Mos. Birth-to-End Survey & $\begin{array}{l}11.69 \\
(5.13)\end{array}$ & $\begin{array}{l}11.65 \\
(5.09)\end{array}$ & $\begin{array}{l}11.71 \\
(5.15)\end{array}$ \\
\hline
\end{tabular}


medRxiv preprint doi: https://doi.org/10.1101/2020.10.26.20219923; this version posted October 27, 2020. The copyright holder for this preprint (which was not certified by peer review) is the author/funder, who has granted medRxiv a license to display the preprint in perpetuity.

All rights reserved. No reuse allowed without permission.

\begin{tabular}{|c|c|c|c|c|c|}
\hline Northeast Census Region & $\begin{array}{c}0.15 \\
(0.36)\end{array}$ & 0.12 & $(0.33)$ & $\begin{array}{c}0.16 \\
(0.37)\end{array}$ & * \\
\hline Midwest Census Region & $\begin{array}{c}0.21 \\
(0.41)\end{array}$ & 0.23 & $(0.42)$ & $\begin{array}{c}0.21 \\
(0.41)\end{array}$ & \\
\hline South Census Region & $\begin{array}{c}0.36 \\
(0.48)\end{array}$ & 0.39 & $(0.49)$ & $\begin{array}{c}0.35 \\
(0.48)\end{array}$ & + \\
\hline West Census Region & $\begin{array}{c}0.27 \\
(0.45)\end{array}$ & 0.26 & $(0.44)$ & $\begin{array}{c}0.28 \\
(0.45)\end{array}$ & \\
\hline \multicolumn{6}{|l|}{ Birth Years: } \\
\hline 2008 & $\begin{array}{c}0.14 \\
(0.35)\end{array}$ & 0.14 & $(0.35)$ & $\begin{array}{c}0.14 \\
(0.35)\end{array}$ & \\
\hline 2009 & $\begin{array}{c}0.12 \\
(0.32)\end{array}$ & 0.12 & $(0.33)$ & $\begin{array}{c}0.12 \\
(0.32)\end{array}$ & \\
\hline 2010 & $\begin{array}{c}0.11 \\
(0.31)\end{array}$ & 0.09 & $(0.29)$ & $\begin{array}{c}0.12 \\
(0.32)\end{array}$ & \\
\hline 2011 & $\begin{array}{c}0.11 \\
(0.32)\end{array}$ & 0.12 & $(0.32)$ & $\begin{array}{c}0.11 \\
(0.31)\end{array}$ & \\
\hline 2012 & $\begin{array}{c}0.12 \\
(0.33)\end{array}$ & 0.12 & $(0.32)$ & $\begin{array}{c}0.12 \\
(0.33)\end{array}$ & \\
\hline 2013 & $\begin{array}{c}0.12 \\
(0.32)\end{array}$ & 0.12 & $(0.33)$ & $\begin{array}{c}0.11 \\
(0.32)\end{array}$ & \\
\hline 2014 & $\begin{array}{c}0.10 \\
(0.30)\end{array}$ & 0.11 & $(0.31)$ & $\begin{array}{c}0.10 \\
(0.29)\end{array}$ & \\
\hline 2015 & $\begin{array}{c}0.09 \\
(0.29)\end{array}$ & 0.10 & $(0.30)$ & $\begin{array}{c}0.09 \\
(0.29)\end{array}$ & \\
\hline 2016 & $\begin{array}{c}0.09 \\
(0.29)\end{array}$ & 0.08 & $(0.27)$ & $\begin{array}{c}0.09 \\
(0.29)\end{array}$ & \\
\hline Observations & 2245 & & 574 & 1571 & 2245 \\
\hline
\end{tabular}

Source: Authors' analysis of births in the Agency for Healthcare Research and Quality's Medical Expenditure Panel Survey (2008-2016) among opioid-naive women without multiple pregnancies.

Notes: $E D=$ Emergency Department; $R x=$ Prescription; OR = Odds Ratio; HS = High School; Deg. = Degree;

$F P L=$ Federal Poverty Level; Mos. $=$ Months

Standard deviations in parentheses

Statistically significant differences in means by opioid receipt determined using the Student's T-test in Stata 15.

$+\mathrm{p}<0.1, * \mathrm{p}<0.5,{ }^{*} * \mathrm{p}<0.01$ 
medRxiv preprint doi: https://doi.org/10.1101/2020.10.26.20219923; this version posted October 27, 2020. The copyright holder for this preprint (which was not certified by peer review) is the author/funder, who has granted medRxiv a license to display the preprint in perpetuity.

All rights reserved. No reuse allowed without permission.

Table 2. Model Results.

\section{Any ED Visit}

\begin{tabular}{|c|c|}
\hline & OR $(p)$ \\
\hline Any Opioid Rx & $1.69 *(0.02)$ \\
\hline Vaginal Delivery & Ref. Cat. \\
\hline Caesarean Delivery & $1.17(0.50)$ \\
\hline White & Ref. Cat. \\
\hline Black & $1.35(0.25)$ \\
\hline Hispanic & $0.63+(0.08)$ \\
\hline Asian & $0.43(0.23)$ \\
\hline Other Race & $1.15(0.77)$ \\
\hline Mother's Age & $0.96 *(0.03)$ \\
\hline No HS Deg./GED & Ref. Cat. \\
\hline HS Deg./GED & $1.66+(0.08)$ \\
\hline Some College/Associate's Deg. & $1.86 *(0.04)$ \\
\hline Bachelor's Deg. or Higher & $1.11(0.81)$ \\
\hline Insured & $1.31(0.33)$ \\
\hline Income $<100 \% \mathrm{FPL}$ & $1.23(0.33)$ \\
\hline Family Size & $0.98 \quad(0.76)$ \\
\hline Married & $0.88 \quad(0.64)$ \\
\hline Northeast & Ref. Cat. \\
\hline Midwest & $0.57 *(0.04)$ \\
\hline South & $0.62+(0.07)$ \\
\hline West & $0.48 *(0.02)$ \\
\hline Constant & $0.12 * *(0.00)$ \\
\hline Mos. Birth-to-End Survey & Yes \\
\hline Year F.E. & Yes \\
\hline Survey Weights & Yes \\
\hline Observations & 2,245 \\
\hline F-Statistic & 5.14 \\
\hline
\end{tabular}

Exponentiated coefficients

Source: Authors' analysis of births recorded in the Medical Expenditure Panel Survey (MEPS), 2008-2016. All models conducted using the logit command in Stata 15 and the MEPS survey weights to make estimates nationally representa- 
medRxiv preprint doi: https://doi.org/10.1101/2020.10.26.20219923; this version posted October 27, 2020. The copyright holder for this preprint (which was not certified by peer review) is the author/funder, who has granted medRxiv a license to display the preprint in perpetuity.

All rights reserved. No reuse allowed without permission.

tive.

Notes: $E D=$ Emergency Department; $R x=$ Prescription; OR = Odds Ratio; HS = High School; Deg. = Degree; FPL = Federal Poverty Level; Mos. = Months; F.E. = Fixed Effects p-values in parentheses

$+\mathrm{p}<0.1, * \mathrm{p}<0.05, * \star \mathrm{p}<0.01$ 
medRxiv preprint doi: https://doi.org/10.1101/2020.10.26.20219923; this version posted October 27, 2020. The copyright holder for this preprint

(which was not certified by peer review) is the author/funder, who has granted medRxiv a license to display the preprint in perpetuity.

All rights reserved. No reuse allowed without permission. 